https://doi.org/10.22364/hssl.29.2.01

\title{
SOCIAL MOVEMENTS FOR DEMOCRACY IN POST-COMMUNIST SPACE: TWO REVOLUTIONS IN CZECHOSLOVAKIA $(1968,1989)^{1}$
}

\section{Olena Babinova²}

\begin{abstract}
This article is a comparative analysis of two revolutions in Czechoslovakia in 1968 and 1989. The main question of this article is: Why did the revolution in 1968 fail, but the revolution in 1989 succeed? In this article the main reasons, common features and differences of those two revolutions were analysed and defined. The main conclusion of this article is the fact that a necessary condition for the victory of popular resistance is the support of these manifestations by the military or their non-interference. The 1968 revolution was suppressed as a result of the invasion of the Warsaw Pact troops under the leadership of the Soviet Union, but the events of 1989 were marked by a decision by the country's military leadership on their neutrality.
\end{abstract}

Keywords: Czechoslovakia, democracy, democratic revolution, military in revolutions, social movements.

\section{Introduction}

The goal of this article is to make a comparative analysis of two democratic revolutions in communist Czechoslovakia in the period of Soviet regime.

This article in intends to find an answer on important question: why some democratic revolutions fail and other are successful. The author seeks an answer to this question by analysing two democratic revolutions in communist Czechoslovakia. One of which was suppressed by the military forces of the Warsaw Pact countries, and the other became an example of the peaceful victory of democracy and the democratic aspirations of the people.

This research is guided by the following questions:

1) Why democratic revolution in Czechoslovakia in 1968 failed, but revolution in 1989 succeeded?

1 This research was supported by the National Scholarship Programme of the Slovak Republic for the Support of Mobility of Students and Researchers.

2 Contact Olena Babinova, olena academy@ukr.net, Training and Research Centre “European Partnership” (Ukraine-France). 
2) What is the state of society, its interests and aspirations just before the democratic movements for independence, freedom and human rights?

3) What is the role of the military in democratic revolutions? and

4) What are the basic conditions for a successful democratic revolution?

To answer on these questions and to implement the goal of this article, the two democratic revolutions in Czechoslovakia in 1968 and 1989 have been analysed in this article.

The results of this study are essential for the formation of the main theoretical approaches for the implementation of successful democratic transformations in a peaceful and bloodless way.

\section{The Bloody Failure of the Prague Spring in 1968}

The events of 1968 in Prague continue to arouse great interest among researchers. Significant contribution to the study and analysis of those events was made by such scholars as John Bradley (1992), Marcos Degaut (2019), Pete Dolack (2013), Julia Friday (2011), Ernest Gellner (1995), John K. Glenn (1999), Michèle Harrison (2003), Peter Hames (2013), Mary Heimann (2009), Miklos Kun (1998), William H. Luers (1990), Petr Oslzlý (1990), William A. Pelz (2016), Anna J. Stoneman (2015), Jiri Suk (2018), Marek Thee (1990, 1991), Kieran Williams (1997), and others.

The first attempt of democratisation took place more than 150 years ago in Czech and Slovak lands. According to V. Hloušek (2011), it was difficult process and by the period before the First World War, however, this goal was more or less completed. After the First World War the processes of formation of democracy in the Czech lands only started.

At the same time, the people on these lands suffered from different forms of occupation. During the twenty years from 1918 and until 1938 the country enjoyed a democratic form of governance and market economy. After the German occupation at the end of World War II, people hoped that soviet power will give a possibility to develop the country in democratic direction. However, instead of this, they received a new form of occupation.

As it was noted by A. Stoneman (2015: 103), the citizens of Czechoslovakia endured a tumultuous history of decades of occupation. After declaring its independence in October 1918 in the aftermath of the First World War and the collapse of the Habsburg Empire, Czechoslovakia was initially a thriving, autonomous, constitutional democracy. After just twenty years, however, with the signing of the Munich Agreement on September 29, 1938, the country was "sacrificed" to Nazi Germany. Czechoslovakia was occupied by Nazi forces throughout the Second World War, suffering "repression, exploitation, and extermination. After the war, 
rather than having its constitutional democracy restored, a Soviet-endorsed Communist dictatorship was installed, and the citizens of Czechoslovakia fell behind the Iron Curtain and began to suffer under the most oppressive and rigid regime of any Soviet bloc country, which relied heavily on terror and all but eliminated civil rights.

The most powerful struggle for democracy in Czech Republic started in 1968. K. Williams in The Prague Spring and its aftermath claims that the events of 1968 in Czechoslovakia, usually referred to as the Prague Spring, remain among the most important in the political history of post-war Eastern Europe, and of Europe as a whole (1997: 1). The author analyses the factors in economic and political life of the country before 1968, and defines the main reasons of those events. He notes that "for all their virtues, the reforms of 1968, in intention and execution, amounted to only the liberalization of a Leninist regime, the gradual widening by the ruling elite of non-prohibited zone, the sphere of things permitted, the space where people can feel themselves more or less free" (1997: 3).

In 1968, for almost eight months, the Czechoslovak Socialist Republic was going through a period of profound changes. These transformations were a result of the growing crisis in this relatively prosperous and developed country, in which the political culture had deeply rooted predominantly democratic traditions. All the events started in January 1968, when the reformer Alexander Dubček was elected on the position of First Secretary of the Communist Party of Czechoslovakia. He wanted to give more rights to citizens, including freedom of the media, freedom of speech and freedom of movement. Thus, he wanted to break all elements on which the soviet system was built. Understandably, Soviet Union could not allow the implementation of these changes.

L. Mlechin (2012) calls these events "a revolution" and gives it the name "a revolution of the spirit". He defines that the changes in the country coincided with the advent of spring. This update went down in history as the Prague Spring. "It delivered the country from fear. People got the right to speak freely, censorship disappeared, and the country changed. The people believed Dubček. For the first time, the leader of the Communist Party became the people's leader ... It is fair to call those events a revolution. But it was, so to speak, a revolution of the spirit".

Many researchers of the processes of democratisation in postcommunist countries pay considerable attention to the problems of the Prague spring, its role in the formation of democracy and formation of civil society in Czechoslovakia at that time. As it was defined by Lyons Pat and Bernardyová Alžběta, one of the central themes of the Prague Spring era was pluralism and the possibility through reform of developing a socialist democracy and economy that allowed inherent differences to be expressed. This pluralism was an essential characteristic of Czechoslovak society from 
the First Republic (1918-1938); and attempts by the communist regime, as the opening quotation attests, did not create a monist socialist state as the orthodox Soviet model of communism demanded (2011: 107).

It should be noted, that in general, the 1960s of the twentieth century were marked by the growth of popular protests in many countries of the world. However, the most difficult situation was in the countries of the Soviet bloc. It was total censorship, a recession in the economy and, as a result, a low standard of living. Added to this was the lack of the ability to express one's opinion, the inability to read the works of the world's leading contemporaries, since many of them were banned.

By opinion of J. Suk (2018: 764), 1968 symbolises a historic shift that took place worldwide. In the countries of the Soviet bloc, conficting processes were also underway, in which the condemnation of criminal Stalinist policies was mixed with notions of quickly catching up with and surpassing the capitalist countries.

K. McDermott and M. Stibbe (2018: 1) claim that the year 1968 has often been portrayed as a pivotal moment in post-1945 history, characterised by the emergence of a globalised, or at least transnational, youth protest movement that crossed land borders and continents, and was transmitted via television, radio and newspapers to audiences in all parts of the world.

A. Stoneman (2015: 103) describes the situation in the countries of the Soviet camp and in particular in Czechoslovakia as follows: thick barbed wire, ploughed earth, watchtowers, and sentries with shoot-to-kill orders enclosed the country's borders. Political opponents to the dictatorship were purged and executed following show trials. An atmosphere of permanent fear was established, as hidden government informants worked their way into the population to spy upon the citizens, who rapidly became reluctant to speak in public or to one another, not knowing who could be trusted.

Why exactly in 1968 in Czechoslovakia the processes of dissatisfaction with the existing situation had intensified? There were many reasons for the beginning of Prague Spring. The prerequisites of people's desire to change the situation of stagnation and total censorship have been clearly described by M. Kun (1998). In his book Prague Spring - Prague fall he raises some important questions about situation in Czechoslovakia in 1968: What happened in Czechoslovakia? Was there an alternative? Situation just before Prague Spring he describes as following (1998: 209):

"At the turn of the millennium, the people of East-Central Europe live in an age when parliamentary or government crises often jar only on the relatively small political elite, and, at most, affect the stock market. The situation was fundamentally different after Joseph Stalin's death, when every important changing of the guard at the pinnacle of power conveyed an indirect message for the whole of society. In the absence of pluralistic democratic institutions and a free press, even people who were 
disappointed by the socialist regime or were apolitical followed closely news of "public life" about replacements released by party organs. The greater cracks became in the seemingly monolithic party leadership of a country, the greater hopes of those outside the bulwark of the regime that the rigors of dictatorship would perhaps ease a little."

According to W. A. Pelz (2016), beginning in the mid-1960s, there was increasing uneasiness among many about Czechoslovakia's bureaucratic government policy and its record of economic failures. Some radical socialist critics looked to Yugoslavia and argued that the party should relinquish some of its decision-making power to independent institutions, such as workers' councils and trade unions. There was even discussion of the re-establishment of a multi-party system for elections to the Czechoslovak National Assembly. By opinion of J. Hochman (2016: 30), in Czechoslovakia, occasionally interrupted process of relative moderation in internal political and ideological controls had been going on for over five years before 1968. It was taking place in a situation generally characterised by the failure of the regime to admit honestly the crimes committed during the first several years after the takeover of 1948, and to try effectively to redress them as much as possible. The situation has been characterised by the apparent incompetence of the rules in managing the nation's affaires, particularly the economy.

\section{What exactly was in Czechoslovakia and how it was during the Prague Spring}

A lot of citizens were not satisfied by policy of Communist Party. In June 1967, at the $4^{\text {th }}$ Congress of the Writers' Union there were many critics of Communist Party policy in direction of censorship in the field of culture and science. It is clear that any talented person cannot work in the conditions when somebody tells them what to do and what to write. As a result of the absence of any adequate reaction from the side of Communist Party on situation in the country, absence of their desire to make it better, in October 1967, the mass protest students' action was beginning.

W. Pelz (2016: 194), argues that along with intellectuals' protest, there were student demonstrations supported by the party's youth newspaper. When the students accused authorities of police brutality, the trade union newspaper not only agreed with the student complaint, but also stressed the need for establishing regular channels for expressing dissent and obtaining redress of grievances on all important areas.

As it was noted by A. Stoneman (2015: 104), during this period, Czechoslovakia was led by the hard-line KSC (Communist Party of Czechoslovakia) Stalinist Antonín Novotný. The nation underwent major economic decline in the early 1960s, but policies remained stagnant. 
Slovak politician Alexander Dubček was the greatest rival of Novotný, maintaining loyalty to the Soviet Union, but favouring reformed socialism through democratisation and economic reform.

One of the leading persons who criticised the approaches of Communist Party and its leader Antonín Novotný was the Head of Slovak Party organisation Alexander Dubček. He was sure that the motto of central Soviet Communist Party "all power to councils" should find practical implementation in his country, that citizens and their councils must have real power in the country, but not only "on the paper". He did not want to change the communist regime, he wanted to make it better, to make it a power for citizens and society. By his opinion, it was in the context of the main declarative priorities of Soviet communist party and that last one will not be against some improvements in this direction in Czechoslovakia. He supported idea of "socialism with a human face".

At the end of 1967, several meetings of the Communist Party of Czechoslovakia were held. They were voiced by significant criticism of the current situation and activities, or rather the inaction of its leader Antonín Novotný. Thus, many who criticised the situation in the party and in the country were among the party members themselves. K. Williams (1997: 4) states that the power struggle that erupted in late 1967 resulted from the decision of an important faction of party and state officials to trust the population. That a growing number of politicians were ready to trust was in turn possible because of the deep social change that had taken place since the 1950s. He describes the general attitude towards what is happening both among mature functionaries and among younger ones. In particular, he defines the support of the new reform course among the representatives of the old system as follows (1997: 6-7):

"Explanation of liberalization must also factor in the role of ideas, in particular the attraction of the very idea of a principled redesign of the system. This holds true especially for the middle generation of party functionaries, those who became communists after 1938 or 1945 , had vigorously served the post-war construction of a new society on the Soviet model, and who began to have second thoughts once they saw the fruits of their labour."

The attitude of more young party functionaries to possible reforms $\mathrm{K}$. Williams explains as reaction on the general revival of legal thought and as their more optimistic approach to cooperation with citizens as a whole. By his view, the younger an often more optimistic party functionaries took the line on the "all-people's state" more seriously and concluded that it demanded a matching change in how the country was governed. This rethinking of the role of the state was accompanied by the general revival of legal thought. Some of the legal reforms enacted in the first half of the 1960s, such as the new penal code in 1961 and new civil code in 1964, were 
in fact considerable deviations from Czechoslovakia's Roman-law tradition, as they glossed over the complexities of ownership rights and took a rather naive view of relations between citizens of a socialist state (1997: 8).

On January 5,1968 , the main ideologist of the changes in the country Alexander Dubček was elected on the position of First Secretary of the Communist Party of Czechoslovakia. And A. Novotný remains in the position of the president of the Republic.

L. Mlechin (2012) thus describes the reaction of Brezhnev and the Soviet government as a whole to the ongoing changes in Czechoslovakia: "Leonid Ilyich Brezhnev for a long time could not form his attitude to the Prague Spring. He was confused, faced with an incomprehensible phenomenon. When East Germans, Hungarians or Poles revolted, they hated their power. And in Czechoslovakia, power and people were together. Eighty percent of the population support the policies of the Communist Party and unconditionally speak out for socialism. From all this, the Moscow leaders simply took a rash decision."

The main directions of the reform, proposed by A. Dubček, were the following: abolish censorship, give more power and authority to the councils of workers and peasants, divide the activities of the party and the government, strengthen the ability of citizens to participate in decision-making processes and strengthen the interaction of government representatives with the population, give the citizens more rights and freedoms, etc.

These directions have been defined in the Action Programme, which was adopted by Communist Party of Czechoslovakia in April 1968. However, this caused a very mixed reaction in the Soviet Union. McDermott and Stibbe (2018: 5) note that the Action Programme, ratified by the Communist Party Central Committee on 5 April 1968, encapsulated both the hopes and limitations of the Prague Spring. This eclectic document was riddled with ambiguities and compromises, but endeavoured to institutionalise a division of power in the communist system, projected economic de-centralisation, safeguarded democratic civil liberties, including the freedom of press, assembly, association and foreign travel, posited, uniquely for a communist government, full political and civil rehabilitation of victims of Stalinist illegalities, and recognized the autonomy of artistic and cultural organisations. As such, the Programme was broadly welcomed by the Czechoslovak public, but it did no go down well in the Kremlin, Brezhnev ominously describing it as an example of "petty-bourgeois spontaneity" and "a bad program that opens up the possibility of the restoration of capitalism".

By opinion of K. Williams (1997: 10-11), liberalisation began because it was a strategic choice consciously taken by a faction of the incumbent political elite. At the same time, of course, constraints existed on the 
range of choices open to them in deciding what this liberalisation should entail. In 1968 the division of Europe automatically ruled out the restoration of large-scale private enterprise or unfettered liberal democracy in a Soviet satellite. Williams defined four reasons of why Soviet hegemony was not feared or resented by liberalisers. First, the Dubcek leadership launched its reforms in the belief that they enjoyed the tacit approval of Moscow, as the entire Soviet commonwealth would benefit from a revitalised Czechoslovakia. Second, Czechoslovak liberalisers were still under the impression that the changes wrought by Nikita Khrushchev, despite his downfall, had made the USSR a more tolerant hegemon; Leonid Brezhnev was regarded as a transitional, and transitory figure. Third, since no Soviet units were based within their borders, Czechoslovak reformers suffered from a delusion of sovereignty. Finally, membership in the Soviet sphere of influence would allow a state to pursue unconventional political and economic arrangements that in the West would be quickly overwhelmed.

Some important role in the development of the country under the new conditions was assigned by Dubček to the workers' councils. By opinion of P. Dolack (2013: 374), workers' councils became a solution to two problems the problem of creating a structure for employees to meaningfully exercise control over their workplaces and as a way to bind together different enterprises so that economic activity would beneat the country as a whole. The state was the owner of enterprises, carrying out all the prerogatives of ownership, including decision making and appointments to managerial positions, without input from below, although the state was in theory the "owner" in the concept of the "representative of," or "in trust for," the people of the country as a whole. The mechanisms of activity workers' councils, their impact on the processes inside of enterprises were clearly defined. P. Dolack describes it as follow (2013: 375):

"It is only fair, the advocates of workers' councils argued, for the workers to have a large say in how their enterprise will be run if they were to shoulder the risks that would result from restructuring management. The creation of the councils would bind together the enterprises, retaining the efficiency inherent in planning as opposed to the chaos of individual enterprises or factories each making decisions in isolation from all others, because the workers' councils would be connected horizontally with regional and national federations or congresses, which would help prepare national production plans based on the needs of producer and consumer goods at the local levels."

In general, one of the important reasons of the proposed reformation was that the power was concentrated in the hand of a small group Presidium of the Communist Party and did not belong to the people and the councils of citizens, although this was the main slogan of the party. 
The Soviets did not know what to do with Czechoslovakia, with the active processes of liberalisation, but they were sure that it needed to suspend these processes. The USSR did not believe the assurances that reforms would only strengthen the bloc. As it was defined by Pete Dolack (2013: 377), the Soviet leadership's unshakable conviction of the rightness of its political monopoly guaranteed that any attempt at loosening party control in Czechoslovakia would be an anathema. Nor would repeated assurances that there would be no break with the Soviet bloc or a withdrawal from the Warsaw Pact have any effect, despite Czechoslovak party leaders' repeatedly stated convictions that they could only achieve their goals of renewing socialism with the protection of the bloc.

The soviet totalitarian system did not use any political methods of conflict resolution. Only one appropriate and possible method of it for this totalitarian regime was utilisation of military force. In August 1968, a military operation "Danube" was started. The armies of the Warsaw Pact countries except Romania, on August 21, 1968 entered in Czechoslovakia, suppressing local communists attempt to become independent from Moscow and Soviet influence. Warsaw pact troops crossed the border of Czechoslovakia at several points. As a result of this invasion, more than a hundred people were killed and several hundred wounded. It was the end of the "Czech miracle" and "Prague Spring". The Soviet army was in Czechoslovakia till 1991.

Those events have been described as follows:

"In the morning hours of August 21, 1968, the Soviet army invaded Czechoslovakia along with troops from four other Warsaw Pact countries. The occupation was the beginning of the end for the Czechoslovak reform movement known as the Prague Spring. The reform movement had been brewing for years, fed by economic problems as well as growing demands from Communist intellectuals for more freedom and pluralism within a socialist system...Meanwhile, Communist leaders elsewhere in Central Europe began to express more and more reservations about the reforms; during the spring, Warsaw Pact troops began manoeuvres on Czechoslovak territory." 3

According to K. Williams (1997: 112), during the night of 20-21 August, under the code-named Operation Danube, an invasion coalition led by the Soviet Union moved 165.000 soldiers and 4600 tanks into Czechoslovakia from southern Poland, the GDR, and northern Hungary. Within a week, after further contingents arrived, approximately half a million foreign soldiers and more than 6000 tanks were roaming over Czechoslovak

3 The Soviet Invasion of Czechoslovakia: August 1968. Materials from the Labadie Collection of Social Protest. https://deepblue.lib.umich.edu/bitstream/handle/2027.42/ 117511/Prague_Spring.html 
territory. Although they started seizing state offices and utilities, the armies had not been dispatched to establish an occupation government. Their arrival was coordinated with Czechoslovak conservatives and neoconservatives who had signalled their willingness to take power and fulfil all the promises made by Dubček. Knowing that they could not rely on the support of the pro-reform Czechoslovak army officer corps or of the bewildered security police, these conspirators in Prague and Bratislava needed external intervention, a coup de main to support their coup d'état.

J. Friday (2011: 164) analysing the events in Prague in 1968 gives some very interesting facts of citizens' resistance to Soviet troops:

"Similar to most colonial powers, the Soviet Union used the process of naming to assert its dominance in territories it possessed... One of the tactics deployed by the citizens of Prague during the first few days of the invasion capitalized precisely on this dynamic: in order to confuse the invading military and hamper their movement through the city, they decided to rewrite or erase the names of the streets and other directional markers."

She notes that the immediate impact of the military intervention in Czechoslovakia was tremendously disorienting: resounding chaos in the streets, tanks and foreign troops everywhere, gun shots heard throughout the city (2011: 165). By author's opinion, Wenceslas Square is a site closely associated with the construction of the Czech nation-state and shaping of Czech identity. Indeed, the occupying forces were aware of the site's importance, both strategic and symbolic. During the invasion, Wenceslas Square was where thousands of people mounted protest markings written either in Czech or Russian. Signs appeared on buildings, street markers, and monuments. The people of Prague not only defaced the architecture of the square; they themselves also became embodied signs of protest, carrying slogans protesting the invasion on their bodies (pp. 166-167).

V. Skutina (1988) in The Russians Are (Really) Coming! describes his personal emotions in the first minutes of Soviet invasion. This description is through the eyes of an eyewitness: It was after midnight, Wednesday, 21 August 1968... I was sleeping, filled with indomitable optimism that after the Czechoslovak Spring and the turbulent summer, a golden autumn of socialism with a human face would finally arrive. The telephone rang... This midnight ring on 21 August 1968 was precisely one of those important cases among thousands of useless awakenings. Boys from the Literarni Listy called and asked me to turn on the radio. They said we were being occupied (1988: 67)... Twice or three times armoured vehicles of the occupants passed through Gorky Square, back and forth, as if they were looking for direction, as if they were searching for something. Later they returned from somewhere around the Main Railroad Station and turned their guns against the building of the National Assembly and partly 
against the building of the Czechoslovak NV. Then stupefied soldiers with loaded automatic weapons jumped out, ready for a clash. We heard them stamping their feet on the stairs and then in the studio on the first floor. We sat down in a half circle and expected the worst. Finally, with a kick, the door opened, and several fussy soldiers of the Soviet Red Army barged in with submachine guns aimed at our chests. Behind them stood an office with a gun stretched out in his hand (1988: 69-70).

The next day after invasion, Alexander Dubček and the Prime Minister Oldřich Černík were arrested by Soviet troops. Some other activists of their team were arrested as well. They were seized in the party's headquarter and sent to Moscow. As a reaction to these events, the Czechoslovak delegation immediately left for Moscow. Soviet leaders were forced to react to this and hold appropriate negotiations with them. They allowed Dubček, Černík and other arrested representatives of Czechoslovakia to participate in it. The Soviet leaders sought to sign a document with the Czechoslovak leaders, which would first of all justify the introduction of troops as a necessary measure due to the failure to fulfil the obligations of the Czechoslovak side taken as a result of negotiations in Čierna and Bratislava, and the inability to prevent a possible coup d'état of the "counter-revolutionary forces". It was also required to declare the decisions of the congress of the CPC in Vysocany invalid and postpone the convening of a new congress of the party. Negotiations took place in an atmosphere of pressure and hidden threats. Czechoslovak leaders stated that the deployment of troops was an unprovoked and unjustified step that would entail grave consequences, including internationally. They noted that the goals set by the leaders of the USSR could be achieved by other, non-military means.

It is important that all this has happened at a time when the tanks of occupants ploughed the streets of Prague and every minute there was a threat of bloodshed. At that time, there were already the first victims. According to modern data, during the invasion, 108 were killed and more than 500 citizens of Czechoslovakia were wounded, the vast majority of civilians. On the first day of the invasion alone, 58 people were killed or mortally wounded, including seven women and an eight-year-old child ${ }^{4}$.

As a result of negotiations in Moscow, in order to avoid further bloodshed and casualties among civilians, A. Dubček and his comrades decided to sign the Moscow Protocol (only F. Kriegel refused to sign it), having only agreed with the decisions of the January and May (1968) Plenums of the Central Committee of the Communist Party and the

4 Ввод войск в Чехословакию. https://ru.wikipedia.org/wiki/ Ввод_войск_в_Чехословакию(1968)\# cite_note-rg-18 
promise to withdraw troops in the future. The result of the negotiations was a joint communiqué in which the timing of the withdrawal of the Soviet troops was made dependent on the normalisation of the situation in Czechoslovakia.

The resistance of the Czechs and Slovaks to the Soviet invasion was so strong that the Soviet power, even after the occupation, made certain concessions. Federalisation was one of the requirements of citizens of Czechoslovakia.

Many scholars call the Prague Spring the "dream". J. Suk (2018: 767) argues that the Prague Spring had an almost messianic dimension. By author opinion, the memorable resistance to the military assault elevated "democratic socialism" to a symbol that, however, defeat rendered too lightweight. The capitulation of the political representatives and the inevitable adaptation of most of society to the "normalised" regime broke the socialist utopianism in two. The restoration of order was based on the repudiation of the collective dream in the name of cold reality. It was banal utilitarianism in politics and everyday life that crushed this dream.

Indeed, the Prague Spring was a dream which did not come true because of soviet military invasion, but it laid the foundations for future resistance. As a result of the invasion, not only in Czechoslovakia, but also in all other countries of the Soviet bloc, it was understood that 1) the Soviet power was deceiving not only its people, but the whole world, declaring that this power was built on the power of workers and peasants, but on in fact, it is built on the power of a separate group of people with an extremist attitude towards the entire civilised world; 2) Soviet power is not a friend, but an enemy of the people; and 3) given the military force of the Soviet bloc, all those who want and are ready to resist must lie low and wait for the right moment. And this moment came in the late 1990s. In Czechoslovakia that period will be called Velvet Revolution.

\section{The Bloodless Success of the Velvet Revolution}

The year 1989 was a beginning of new protests, which were called the "Velvet Revolution". In November 17, 1989 in Czechoslovakia began street students' protests. This day in Prague student demonstrations began, initiating a "velvet revolution" - bloodless overthrow of the communist regime in Czechoslovakia. These events have radically changed the political situation in the country. The first actions of protests in society began in 1988, but they were dispersed by police. The next series of mass demonstrations took place in November 1989. Police answered by acceleration, repression and arrests. But these events have launched the process of dismantling the socialist system. The success of the Velvet 
Revolution was supported by a favourable international situation (fall of the Berlin Wall and "perestroika" in the Soviet Union).

For many of post-communist countries the processes of fighting for their democratic future were not easy and bloodless. When in 1968, the Czechoslovakia decided to go in the direction of reinforcement of human rights and freedoms, to give the citizens some democratic possibilities to have an impact on power, the soviet tanks were in Prague. Some years before, the same situation was in Hungary and Poland. However, the events in Czechoslovakia in 1989 have shown that it is possible to make bloodless changes, if representatives of the power, opposition and military leaders are thinking about their citizens and therefore can find a compromise through the process of negotiations. That is why the relevant experience of Czechoslovakia is so important.

M. Degaut (2019) in analysing the role of military in democratic revolutions concludes that the military backing is a necessary condition for a democratic revolution to succeed. He defines that in fact, it seems that the military backing of a revolution, or at least its neutrality toward it, is a necessary condition for a democratic revolution to succeed. If the armed forces protect the political establishment, the revolutionary opposition will very likely not be able to seize power; however, if the military do not protect the regime, or if they are indifferent to its fate, then the revolutionary movement will probably come to power as it removes the means and resources that a regime would have to ensure its survival (p. 81).

T. Kuran (1991) in Now Out of Never. The Element of Surprise In The East European Revolution 1989 describes events of 1989 in Europe as an unexpected situation. He notes that many of people including politicians and scholars did not wait that the actions of protests will have some stable results and will changed the situation significantly. He quotes the statements of Vaclav Havel before the events of 1989 where V. Havel expresses the opinion that these events will serve as "the seed of something that will bear fruit in the distance future" (1991: 9). Kuran gives some extracts from the public opinion poll which was conducted by Allensbach Institute four months after the fall of communism in East Germany. The people were asked the question: "A year ago did you expect such a peaceful revolution?" The results of this opinion poll were the following: Only 5 percent answered in the affirmative, although 18 percent answered "yes, but not that fast". Fully 76 percent indicated that the revolution had totally surprised them (p. 10). At the same time, Kuran claims that it might be said that some very knowledgeable observers of the communist bloc had predicted its disintegration before the century was out. As early as 1969 , for instance, the Soviet dissident Andrei Amalrik wrote that the Russian Empire would break up within a decade and a half. Although it is tempting to credit Amalrik with exemplary foresight, a rereading of his famous essay shows 
that he expected the Soviet Empire to meet its end following a protracted and devastating war with China, not through a string of popular upheavals (p. 11). However, maybe his foresight will be realised in the future. It would be difficult to agree with Kuran if he noted that the social movements of 1989 were fully unexpected as well as their results. And really, he adds that "this is not to suggest that the East European explosion came as total surprise to everyone. Though most were astonished when it happened, and though few who saw it coming expected it to be so peaceful, a small number of commentators had prophesied that the revolution would be swift and remarkably bloodless" (p. 12). He concludes that "this tally of unanticipated uprisings could be expanded, but the point has been made: the revolution of 1989 was not the first to surprise us. Time and again entrenched authority has vanished suddenly, leaving the victors astonished at their triumph and the vanquished, at their defeat" (p. 45).

M. Thee (1991) supports the notion of T. Kuran that the peaceful revolutions in many East European countries were unexpected and surprised. He states that "the abrupt collapse in 1989 of the totalitarian 'people's democracies' in the outer perimeters of the Soviet empire in Central-Eastern Europe, in the arc from Eastern Germany to Bulgaria, has taken an entire world by surprise. This was a unique cataclysmic event. Indeed, we lack a proper theory of history to explain fully the phenomenon of a largely nonviolent, except for Romania, rapid overthrow and definite demise of an authoritarian socio-political system on so broad a front, combined with the breakout from the still-functioning empire that installed and protected this system" (1991: 241). He claims that the results of these events were surprised not only for political scientists, historians and politicians, but even for the actors themselves that they did not anticipate such a fast and expeditious powershift. The author analyses some prerequisites of the velvet revolution in 1989, and defines that the main of them was the crisis in political, cultural, economic, spiritual, ideological domains of the Soviet regime. He argues that the basis for the events of 1989 was created before - by mass protests' actions in the DDR in 1953, in Poland and Hungary in 1956, in Czechoslovakia in 1968, and again in Poland in 1980/81.

The beginning of restructuring processes in USSR ("Perestroika") prompted opposition in Czechoslovakia to more decisive action. In November 29, the Parliament of the country abolished the article of the constitution on the leading role of the Communist Party. In December 29, by the reorganised parliament was elected as its chairman Alexander Dubcek, as the president of Czechoslovakia - the head of the Civic Forum Václav Havel.

The reasons of revolution in 1989 in Czechoslovakia are clear described by John Glenn in his book Framing Democracy. Civil Society and Civic 
Movements in Eastern Europe (1999). He claims that Czechoslovakia was one of the most repressive states in Eastern Europe before 1989, with a weak and fragmented democratic opposition; yet, strikingly, the reconstruction of the state took place faster there than in other Eastern European countries and arguable led to more radical changes (1999: 130).

P. Hames (2013: 41) in The Czech and Slovak Republics: The Velvet Revolution and After considers two options of velvet revolution in the context of their expectation as anticipated and sudden. He puts a question: Was the Velvet Revolution of 1989 a revolution or the links of one chain events in other countries of the communist camp? He notes that the collapse of Communism in Czechoslovakia in 1989 was both inevitable and unexpected, and that in finding the answer to this question, much depends on definitions and perspectives. Some have argued that, since the initiatives for change came from outside the power structure, it could be seen as such, while others have claimed that it was no more than the consequence of prior events in Poland, Hungary, and East Germany. However, while it is true that the Velvet Revolution was dependent on the crisis in the Soviet system as a whole, there was also evidence of change within Czechoslovakia itself.

\section{What was in Czechoslovakia in November 1989}

The first actions of protests in society began in 1988, but they were dispersed by police. The next series of mass demonstrations took place in November 1989. Police answered by acceleration, repression and arrests, but these events have launched the process of dismantling the socialist system. In November 1989, citizens of Czechoslovakia took to the streets, demanding the end of the communist regime. The Velvet Revolution in Czechoslovakia began on November 17, 1989. On that day, Czechoslovak special forces brutally dispersed a student demonstration, the participants of which deviated from the route authorised by the special power authorities and went to the centre of Prague. Someone made a rumour that student was killed during the crackdown instantly became an impetus for anti-government protests. Leaders of unofficial opposition groups created the Civic Forum political movement, Prague students announced a strike on November 20, and all higher educational institutions of the country joined it on the very first day. The Velvet Revolution was gradually gaining momentum: anti-government protests are becoming more severe every day; a general strike was held in the country. The military and the police decide not to intervene. This decision has influenced the results of the popular protests. As a result of the protests, the Central Committee of the Communist Party of Czechoslovakia resigned. December 29, 1989 in the Vladislav Hall of Prague Castle, a joint meeting of both houses of 
the Federal Assembly of Czechoslovakia was held, at which Vaclav Havel was elected on the post of the President. The election of Havel was the last chord to complete more than four decades of communist rule in Czechoslovakia. Velvet revolution received this name because it was bloodless social movement that led to the victory and regime change in a bloodless way.

The success of the Velvet Revolution was supported by a favourable international situation (fall of the Berlin Wall and "perestroika" in the Soviet Union). The beginning of restructuring processes in USSR ("Perestroika") prompted opposition in Czechoslovakia to more decisive action. In November 29, the Parliament of the country abolished the article of the constitution on the leading role of the Communist Party. In December 29, by the reorganized parliament was elected as its chairman Alexander Dubcek, as the president of Czechoslovakia - the head of the Civic Forum Václav Havel.

M. Degaut (2019) pointed out that the 1989 Velvet Revolution in Czechoslovakia was an example of peaceful changes of authoritarian regime to democratic because of military backing in the view of neutrality, which is, by scholar opinion, important aspects for successful bloodless revolutions. He concludes that "the army's neutrality was crucial to the success of the revolution. Without the protection of the state coercive apparatus, the entire Czechoslovak Politburo was forced to resign on November 29, paving the way for the 1989 democratic elections, won by Vaclav Havel, a former dissident playwright" (3: 91).

M. Tůma (2006: 6) in Defence Transformation in the Czech Republic underlined that the Czechoslovak People's Army (CSPA) was a pillar of the Communist regime, controlled by and loyal to the Communist Party. Shifting the control and loyalties of the CSPA to the country's new political elite and cutting old CSPA links with the Communist Party were urgent priorities for the democratic movement during and immediately following the Velvet Revolution. He added that from 1990 public-military relations benefited from the influence of newly created 'councils for public contact'. These forums were intended to improve the transparency of military activities, raise the military's prestige and win greater public support for the democratization, professionalization and transformation of the armed forces (2006: 10).

In $1^{\text {st }}$ January 1993, Czechoslovakia ceases to exist, and on its place arose two new states - the Czech and Slovak Republics.

Division of Czechoslovakia and creation of these states have had a historical basis.

The reasons of this division were defined by Zaninovich and Brown in Political Integration in Czechoslovakia: The Implications of the Prague Spring and Soviet Intervention (39: 66-67). The authors claim the fact that the Czechs and Slovaks shared a related ethnic heritage was not sufficient to overcome 
the cultural and economic cleavages between the two nationalities. These cleavages had their source, initially, in the tenth century Hungarian conquest, which led to the separation of Slovakia from the Czech lands for the next thousand years. Even though a longing for reunion between these related Slavic people existed through the centuries, the isolation of the Slovaks resulted in a fervent nationalism based upon their unique historical experience and a distinctly separate Slovak language. By scholars' opinion, during the half-century prior to World War I, the Czechs had been preoccupied with their conflict and competition with the Germans, while the Slovaks were energetically and successfully resisting forced assimilation by the Magyars. Because of their association with the Austrian state during this period, the Czechs in Bohemia and Moravia also experienced a steady industrial growth, while the Slovaks retained their traditional agricultural orientation and remained economically less developed. As a result, there were substantial differences between the two peoples when they joined to create the Republic of Czechoslovakia in 1918.

Rupinder K. Randhawa in Velvet Revolution to Transition: The Czech Republic's Success Story describe the situation with self-determination of Czech and Slovak Republics just after "Velvet Revolution" as follows (2002: 166):

"Due to the positive developments that came with the collapse of communism and victory of "Velvet Revolution" all the weaknesses of new political movement and political parties were forgotten. Both the Civic Forum and Public Against Violence were two forces which formed coalition against communism, but in reality both of these possessed contrasting perspectives and were together because of their anticommunist stance and leading role in the revolution. Soon after the elections the elements which bound both of these together, started breaking apart because their leaders possessed different outlooks and wanted to direct country's economy and politics to divergent directions. These developments were simultaneously accompanied by the fears about the continued co-existence of the Czechs and Slovaks in a viable joint state. Hence the initial euphoria following the overthrow of communist regime slowly started cooling down and the differences between the Czechs and Slovaks started emerging. In Slovakia a movement in favour of creation of an independent Slovak state began to gather increasing momentum."

By opinion of Luers (1990: 89-90, 98], Czechoslovakia's own communist government and that of the Soviet Union over the past forty years have manipulated the relations between Czechs and Slovaks for their own purposes. He argued that Slovak students and intellectuals clearly played an important role in liberation of Slovakia with their Public Against Violence organisation - the equivalent to the Czechs' Civic Forum. However, the different ways in which the Slovak and Czech peoples have dealt over the 
past decade with communism will add one more complexity to the troubled relations between these two principal nations of the Czechoslovak state. He concludes that the revolution was a popular and peaceful uprising driven and controlled by spontaneity and improvisation. The Czechoslovak people had swept aside their own government and the Civic Forum, as the only alternative group left in the society with some organisational ability and moral authority, simply filled the vacuum.

In the Czech and Slovak Republics the day November 17 is recognised and declared as national holiday - the Day of the struggle for freedom and democracy.

\section{Conclusion}

The purpose of this article was to analyse two democratic revolutions in Czechoslovakia in 1968 and 1989, to define their successful and unsuccessful steps, elements, and approaches, to conclude the main reasons their failure and victory.

Thus, two revolutions in Czechoslovakia in 1968 and 1989 have shown that:

- it is impossible to crush a popular uprising when it has a truly massive character;

- democratic revolutions in Central and Eastern Europe would have happened much earlier if the Soviet military and their tanks had not taken part in the suppression of protests;

- any power must understand and remember that it is not unlimited and that abuse of it will necessarily be punished;

- reaction of military and police on popular uprisings is important aspect of their victory or defeat. There are many countries in the world where citizens are trying to force regime change during mass protests' actions without any success. In many of these cases, it will be possible to achieve this democratic goals only by backing of national military. Therefore, significant work with this group of society should precede popular democratic revolts to succeed.

In general, democracy is a basis and main element for development of open society - society in which citizens have the real power to influence on the process of decision-making in the country; in which governmental bodies are responsible and responsive to citizens' needs; where the system of public control is effectively functioning.

In any society and under any regimes, people have always sought to live in democracy, to have democratic freedoms and to have power which will be responsible and responsive to the citizens' needs. History knows many democratic movements, popular uprisings and revolutions. Some of them were successful, and some were not. 
The revolutions of 1968 and 1989 in Czechoslovakia have shown that military support is an important aspect of successful revolution. The popular uprisings of 1968 had a great chance of success - the initiative came not only from the people, but also from the government itself, which in turn developed a clear program of social and democratic changes. It was a unique example when power representatives and citizens were ready to make the common positive changes in the country together. It was the situation when power and citizens wanted the same changes and they were ready to implement them. Only soviet invasion put an end to their hopes and plans.

The Velvet Revolution, unlike the Prague Spring, was not so well prepared; it did not go through the stage of development and partial implementation of the program of democratic reforms. It was spontaneous. And the decisive factor here was the fact that no military force was used against the demonstrators, not only from abroad, as was the case with the Prague Spring, but also of the local military.

Analysing the reasons of these two revolutions, it is possible to conclude the following:

1. Significant pressure on democratic freedoms, censorship and other violations of human rights in any case will lead to mass protest's social movements and/or to revolution.

2. At the moment when the discontent of the people by the incumbent regime reached its apogee, it will be enough a small event to start the popular uprisings. No political regime should bring its people to a boiling point if they do not want to get a revolution in response to this attitude.

3. The revolution can be suppressed by military force, but this will be a temporary condition. At the first opportunity, if the authorities have not changed their attitude towards the public and have not turned to democratic values and appropriate reforms, popular uprisings will continue until complete victory.

4. Any democratic revolution will be successful if there are two main conditions: 1) the readiness of society as a whole and citizens to take active steps for democratic transformations in the country, and 2) support for transformations on the part of the military, or at least their non-interference. Thus, citizens' desire alone is not enough for a successful democratic transformation in many cases. For the implementation of democratic revolutions, the main condition must be realised - military support of citizens' desire. Therefore, the corresponding preliminary work should be carried out in this direction. 


\section{Acknowledgment}

Author thanks Prof. Emilia Sičáková-Beblava, Director of Public Policy, Department of Faculty of Social and Economic Sciences of the Comenius University in Bratislava and Dr. Lucia Mokrá, Dean of Faculty of Social and Economic Sciences of Comenius University in Bratislava for their comprehensive support of this research.

\section{REFERENCES}

Bradley, John F.N. (1992). Czechoslovakia's Velvet Revolution. A political Analysis. East European Monographs, Boulder.

Czech Republic. Period of democratic transition: 1989-1990 Pro-democracy civic movement: present. Available at: https:/freedomhouse.org/sites/default/files/ inline_images/Czech\%20Republic.pdf (accessed on 10.04.2021).

Degaut, Marcos. (2019). Out of the Barracks: The Role of the Military in Democratic Revolutions. Armed Forces \& Society, Vol. 45(1), 78-100.

Dolack, Pete. (2013). Prague Spring: Workers' Control in a State-Owned Economy. Working USA: The Journal of Labor and Society. Immanuel Ness and Wiley Periodicals, Inc., Volume 16, September 2013, pp. 371-387.

Friday, Julia. (2011). Prague 1968: Spatiality and the Tactics of Resistance. Texas Studies in Literature and Language, Vol. 53, No. 2, Summer, University of Texas Press, pp. 159-178.

Gellner, Ernest. (1995). The Price of Velvet: Thomas Masaryk and Václav Havel. Czech Sociological Review, Vol. 3, No. 1, A Hundred Years of "The Czech Question", pp. 45-57. Published by Institute of Sociology of the Czech Academy of Sciences.

Glenn, John K. (1999). Competing Challengers and Contested Outcomes to State Breakdown: The Velvet Revolution in Czechoslovakia. Social Forces, 78(1), pp. 187212, The University of North Carolina Press.

Harrison, Michèle. (2003). Choosing a Past: Choosing a Future. Lustration and Transition in the Czech Republic. Slovak Foreign Policy Affairs, Vol. 4, No. 2, The Role of History in Politics (Fall), pp. 54-64. Published by Research Center of the Slovak Foreign Policy Association.

Hames, Peter. (2013). The Czech and Slovak Republics: The Velvet Revolution and After. In Cinemas in Transition in Central and Eastern Europe after 1989. Catherine Portuges, Peter Hames (Ed.). Published by: Temple University Press, pp. 40-74.

Heimann, Mary. (2009). Czechoslovakia. The State That Failed. Yale University Press, New Haven and London.

Hloušek, Vít. (2011). The Czech Republic's Transition to Democracy. Available at: https:// cupdf.com/document/2-hlousek-the-czech-republics-transition-to-democracy1.html

Hochman, Jiri. (1988). Words and Tanks: The Revival, The Struggle, The Agony and Defeat (1968-1969). In The Prague Spring: A Mixed Legacy. 1988. Edited by Jiri Pehe. Perspectives on Freedom, No. 3, Freedom House, pp. 27-40.

Jarausch, Konrad H. (2015). Peaceful Revolution. A New History of Europe in the Twentieth Century. In Out of Ashes. Published by Princeton University Press. 
Krejci, Jaroslav; Machonin, Pavel. (1996). Czechoslovakia, 1918-92. A Laboratory for Social Change. Macmillan and St. Antony's College, Oxford.

Kuran, Timur. (1991). Now Out of Never: The Element of Surprise in the East European Revolution of 1989. World Politics, Vol. 44, No. 1 (Oct.), pp. 7-48. Published by Cambridge University Press.

Kumar, Krishan. (1992). The Revolutions of 1989: Socialism, Capitalism, and Democracy. Theory and Society, Vol. 21, No. 3 (June), pp. 309-356. Published by Springer.

Kun, Miklos. (1998). Prague Spring - Prague fall. Blank Spots of 1968. Akadémiai Kiadó, Budapest.

Luers, William H. (1990). Czechoslovakia: Road to Revolution. Foreign Affairs, Vol. 69, No. 2 (Spring), pp. 77-98. Published by Council on Foreign Relations.

Lyons, Pat; Bernardyová, Alžběta. (2011). Satisfied, Sceptical or Simply Indifferent? Current Public Opinion towards the Fall of Communism in the Czech Republic. Europe-Asia Studies, Vol. 63, No. 9, 1989 and Eastern Europe: Reflections and Analyses (November), pp. 1719-1744. Published by Taylor \& Francis, Ltd.

McDermott, Kevin; Stibbe, Matthew (Eds.). (2018). Eastern Europe in 1968. Responses to the Prague Spring and Warsaw Pact Invasion. Palgrave Macmillan.

Matynia, Elzbieta. (2009). Twenty Years Later: A Call for Existential Revolution: Vaclav Havel in Conversation with Adam Michnik. International Journal of Politics, Culture, and Society, Vol. 22, No. 3, 1989 and Beyond: The Future of Democracy (Sept.), pp. 255-262. Published by Springer.

Oslzlý, Petr. (1990). On Stage with the Velvet Revolution. TDR, Vol. 34, No. 3 (Autumn), pp. 97-108. Published by The MIT Press.

Pelz, William A. (2016). From the Berlin Wall to the Prague Spring: A New Generation of Europeans. In A People's History of Modern Europe. Publisher: Pluto Press.

Roberts, Adam. (2009). Civil Resistance Since 1989: People Power: Berlinto Burma. The World Today, Vol. 65, No. 11 (November), pp. 27-29. Published by Royal Institute of International Affairs.

Randhawa, Rupinder K. (2002). India Quarterly, Vol. 58, No. 3/4 (July-December, 2002), pp. 165-176. Published by Sage Publications, Ltd.

Saxonber, Steven. (1999). The 'Velvet Revolution' and the Limits of Rational Choice Models. Czech Sociological Review, Vol. 7, No. 1 (Spring), pp. 23-36. Published by Institute of Sociology of the Czech Academy of Sciences.

Simral, Vit. (2011). The Games of the Velvet Revolution: An Integrative Approach to the Transition in Czechoslovakia 1989. In Perpetual Motion? Transformation and Transition in Central and Eastern Europe \& Russia. Tul'si Bhambry, Clare Griffin (Ed.). Publisher: UCL Discovery.

Skutina, Vladimir. (1988). The Russians Are (Really) Coming! In The Prague Spring: A Mixed Legacy. Edited by Jiri Pehe. Perspectives on Freedom No. 3, Freedom House.

Stoneman, Anna J. (2015). Socialism With a Human Face: The Leadership and Legacy of the Prague Spring. In The History Teacher, Vol. 49, No. 1 (November), pp. 103-125.

Suk, Jiri. (2018). AHR Reflections. The Utopian Rationalism of the Prague Spring of 1968. American Historical Review (June), Oxford University Press, pp. 764-768.

Ther, Philipp. (2016). The Revolutions of 1989-91. In Europe since 1989. Published by: Princeton University Press. 
Tichy, Jindra. (1994). Czech-Slovak split: a velvet divorce? New Zealand International Review, Vol. 19, No. 1 (January/February), pp. 22-24. Published by New Zealand Institute of International Affairs.

Thee, Marek. (1991). The Post-Cold War European Landscape: The Aftermath of the 'Velvet Revolutions' in Central-Eastern Europe. Journal of Peace Research, Vol. 28, No. 3 (Aug.), pp. 241-247. Published by Sage Publications, Ltd.

Thee, Marek. (1990). The Post-Cold War European Landscape: Notes on the "Velvet" Revolutions and Currents in Central-Eastern Europe. Current Research on Peace and Violence, Vol. 13, No. 2, pp. 57-64. Published by: Tampere Peace Research Institute, University of Tampere.

Tismaneanu, Vladimir. (2009). The Revolutions of 1989: Causes, Meanings, Consequences. Contemporary European History, Vol. 18, No. 3, Revisiting 1989: Causes, Course and Consequences (Aug.), pp. 271-288. Published by Cambridge University Press.

The Soviet Invasion of Czechoslovakia: August 1968. Materials from the Labadie Collection of Social Protest. Available at: https://deepblue.lib.umich.edu/bitstream/ handle/2027.42/117511/Prague_Spring.html (accessed on 10.04.2020).

Tůma, Miroslav. (2006). Relics of Cold War. Defence Transformation in the Czech Republic. In Democratic control of the military. Published by Stockholm International Peace Research Institute.

Williams, Kieran. (1997). The Prague Spring and its aftermath. Czechoslovak politics 19681970. Cambridge University Press, 270 p.

Zaninovich, M. George, \& Brown, Douglas A. (1973). Political Integration in Czechoslovakia: The Implications of the Prague Spring and Soviet Intervention. Journal of International Affairs, Vol. 27, No. 1, pp. 66-79.

Ввод войск в Чехословакию. Available at: https://ru.wikipedia.org/wiki/ Ввод_ войск_в_Чехословакию_(1968)\# cite_note-rg-18 (accessed on 10.04.2020).

Млечин, Леонид. (2012). Холодная война: политики, полководцы, разведчики. Центрполиграф, 783 с. 